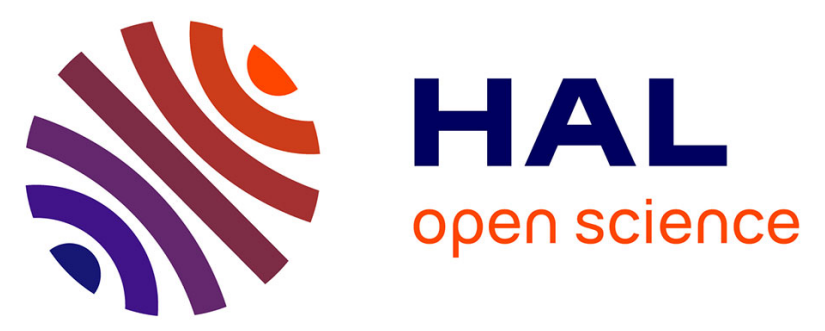

\title{
The zirconium stable isotope compositions of 22 geological reference materials, 4 zircons and 3 standard solutions
}

Shengyu Tian, Edward C. Inglis, John B. Creech, Wen Zhang, Zaicong Wang, Zhaochu Hu, Yongsheng Liu, Frédéric Moynier

\section{To cite this version:}

Shengyu Tian, Edward C. Inglis, John B. Creech, Wen Zhang, Zaicong Wang, et al.. The zirconium stable isotope compositions of 22 geological reference materials, 4 zircons and 3 standard solutions. Chemical Geology, 2020, 555, pp.119791. 10.1016/j.chemgeo.2020.119791 . insu-02943024

\section{HAL Id: insu-02943024 https://hal-insu.archives-ouvertes.fr/insu-02943024}

Submitted on 18 Sep 2020

HAL is a multi-disciplinary open access archive for the deposit and dissemination of scientific research documents, whether they are published or not. The documents may come from teaching and research institutions in France or abroad, or from public or private research centers.
L'archive ouverte pluridisciplinaire HAL, est destinée au dépôt et à la diffusion de documents scientifiques de niveau recherche, publiés ou non, émanant des établissements d'enseignement et de recherche français ou étrangers, des laboratoires publics ou privés. 


\section{Journal Pre-proof}

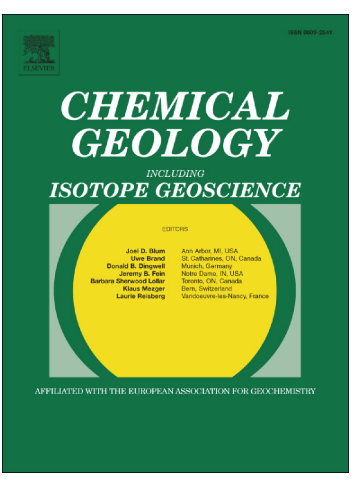

Shengyu Tian, Edward Inglis, John Creech, Wen Zhang, Zaicong Wang, Zhaochu Hu, Yongsheng Liu, Frédéric Moynier

PII: $\quad$ S0009-2541(20)30330-2

DOI: $\quad$ https://doi.org/10.1016/j.chemgeo.2020.119791

Reference: $\quad$ CHEMGE 119791

To appear in: $\quad$ Chemical Geology

Received date: $\quad 1$ May 2020

Revised date: $\quad 13$ July 2020

Accepted date: $\quad 16$ July 2020

Please cite this article as: S. Tian, E. Inglis, J. Creech, et al., The zirconium stable isotope compositions of 22 geological reference materials, 4 zircons and 3 standard solutions, Chemical Geology (2020), https://doi.org/10.1016/j.chemgeo.2020.119791

This is a PDF file of an article that has undergone enhancements after acceptance, such as the addition of a cover page and metadata, and formatting for readability, but it is not yet the definitive version of record. This version will undergo additional copyediting, typesetting and review before it is published in its final form, but we are providing this version to give early visibility of the article. Please note that, during the production process, errors may be discovered which could affect the content, and all legal disclaimers that apply to the journal pertain.

(C) 2020 Published by Elsevier. 


\section{The zirconium stable isotope compositions of 22 geological reference materials, 4 zircons and 3 standard solutions}

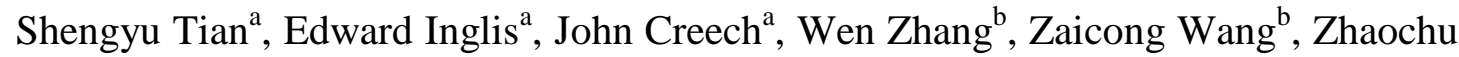
$\mathrm{Hu}^{\mathrm{b}}$ Yongsheng Liu ${ }^{\mathrm{b}}$, Frédéric Moynier ${ }^{\mathrm{a}}$

${ }^{a}$ Université de Paris, Institut de Physique du Globe de Paris, CNRS, 1 rue Jussieu, 75238, Paris cedex 05, France

\section{${ }^{\text {b }}$ State Key Laboratory of Geological Processes and Mineral Resources, School of Earth Sciences, China University of Geosciences, Wuhan 430074, China}

Corresponding authors: tian@ipgp.fr, moynier@ipgp.fr

\section{Abstract}

We report stable $\mathrm{Zr}$ isotope compositions of four common natural zircon grains: Penglai, 91500, GJ-1 and Mud Tank, and 22 whole rocks reference materials which include fifteen magmatic rocks, one metamorphic rock, six sediments or sedimentary rocks. In addition, the isotopic calibration of the three $\mathrm{Zr}$ standard solutions used in different publications (IPGP-Zr, SRM3169, NIST) has been determined. The data are reported as $\delta^{94 / 90} \mathrm{Zr}_{\text {IPGP-Zr }}$, the permille deviation of the ${ }^{94} \mathrm{Zr} /{ }^{90} \mathrm{Zr}$ ratio relative to the IPGP-Zr standard solution. The isotopic offsets among the three $\mathrm{Zr}$ standard solutions are small (less than $0.033 \pm 0.033 \%$ ). The isotopic composition of the zircons agrees well with previous in-situ measurements, validating the in-situ measurements. On the other hand, all the samples analyzed in this study show a large range of $\mathrm{Zr}$ isotope compositions of $0.602 \%$. This confirms the fairly large natural $\mathrm{Zr}$ isotopic variations. The general variation of $\delta^{94 / 90} \mathrm{Zr}_{\text {IPGP-Zr }}$ with magmatic evolution of the various igneous samples is in agreement with previous studies, with the most magmatically evolved 
samples being the isotopically heavier. The two magmatic zircons are isotopically lighter compared to the magmatic rocks, which is in agreement with the enrichment of heavy isotope in the evolved samples. This is ultimately controlled by the crystallization of isotopically light zircons.

\section{Introduction}

Zirconium, as a high-field strength element (HFSE; Zr, Hf, Nb, Ta and Ti), is characterized by a high charge to ionic radius ratio. The study of the chemical abundances of HFSEs have been used to investigate a wide variety of geological processes, including: the evolution of the terrestrial mantle, the genesis and evolution of the continental crust, and the interaction and differentiation history of the mantle-crust system (Condie and Shearer, 2017; Niu, 2004; Pearce and Parkinson, 1993; Salters and Shimizu, 1988; Weyer et al., 2003; Woodhead et al., 1993). Zirconium has five stable isotopes, ${ }^{90} \mathrm{Zr}(51.45 \%) ;{ }^{91} \mathrm{Zr}(11.22 \%) ;{ }^{92} \mathrm{Zr}(17.15 \%) ;{ }^{94} \mathrm{Zr}$ $(17.38 \%)$ and ${ }^{96} \mathrm{Zr}(2.80 \%)$, among which ${ }^{92} \mathrm{Zr}$ is produced by the decay of the extinct nuclide ${ }^{92} \mathrm{Nb}$ with a half-life of $\sim 37 \mathrm{Ma}$ (Iizuka et al., 2016). Because each $\mathrm{Zr}$ isotope was produced predominantly from distinct nucleosynthetic processes or by radioactive decay (Akram and Schönbächler, 2016), the study of $\mathrm{Zr}$ isotopic anomalies has provided constraints on nucleosynthetic sites and time scales in the early Solar System (Iizuka et al., 2016; Schönbächler et al., 2002, 2003). This preferential interest in radiogenic ${ }^{92} \mathrm{Zr}$ and in the search for isotopic anomalies, combined with the analytical difficulties of obtaining complete $\mathrm{Zr}$ yields during ion exchange chromatography, have left the mass dependent fractionation patterns of stable $\mathrm{Zr}$ isotopes largely untouched to date.

The isotopic fractionation of metal elements (such as $\mathrm{Fe}, \mathrm{Mg}, \mathrm{Ti}, \mathrm{Cr}, \mathrm{Zn}$ etc.) have provided important insights in various geological processes, such as: core formation (e.g. Bonnand et al., 2016); mantle melting and metasomatism (e.g. Kang et al., 2017; Wang et al., 2017); magmatic differentiation (e.g. Dauphas et al., 2014), crust - mantle 
interactions (e.g. Inglis et al., 2017), volatile depletion (e.g. Kato and Moynier, 2017), or the formation and evolution of continental crust (e.g. Deng et al., 2019; Greber et al., 2017). Zirconium is one of the most refractory lithophile elements (half-mass condensation temperature of $1736 \mathrm{~K}$ ) (Lodders, 2003). Its abundance in planetary mantles is, a priori, not modified by core formation, late veneer, and volatilization processes (Akram and Schönbächler, 2016; Akram et al., 2015; Palme and O'Neill, 2003). Furthermore, it is considered to be one of the less mobile elements during low pressure low temperature aqueous fluid alteration processes, therefore limiting redistribution by low temperature metamorphic/metasomatic processes (Anderson et al., 2002; Green et al., 2006). Zirconium behaves as a moderately incompatible element during mantle melting with partition coefficient between solid and melt, $\mathrm{D}_{\mathrm{Zr}}$, between 0.073 and 0.123 (Hart and Dunn, 1993; Mallmann and O'Neill, 2009; McDade et al., 2003), which is a key characteristic of the HFSEs. The main host minerals of $\mathrm{Zr}$ within magmatic systems are baddeleyite $\left(\mathrm{ZrO}_{2}\right)$ and zircon $\left(\mathrm{ZrSiO}_{4}\right)$, these occur as common accessory phases across a wide compositional range of igneous rocks (Hanchar and Watson, 2003; Iizuka et al., 2016; Jaakko, 1977; Zhang et al., 2009). Thus, Zr stable isotopes have the potential to provide constraints on primary magmatic processes on both terrestrial and extraterrestrial bodies.

To date there have been relatively few studies of $\mathrm{Zr}$ isotopes within natural settings. Akram and Schönbächler (2016) were the first to report Zr stable isotope variations between pure Zr standard solution. Inglis et al. (2018 and 2019) developed the first stable isotope measurements using a double spike method on multi-collection inductively-coupled-plasma mass-spectrometer (MC-ICP-MS) and found that evolved, felsic igneous rocks were enriched in heavier $\mathrm{Zr}$ isotopes. They suggested zircon saturation and segregation drove the residual melt to be enriched in heavy $\mathrm{Zr}$ isotopes based on the coordination chemistry of zircons relative to silicate melts, with precipitating zircons being isotopically light. Zhang et al. (2019) used a laser ablation in-situ method to analyze $\mathrm{Zr}$ isotope compositions of zircon references and natural 
zircons. They observed a variation of $\sim 0.4 \%$ in the average values of all the zircons, across individual growth zones. Notably, reference material FC-1 zircon showed a significant heterogeneity on the order of $\sim 5 \%$ of $\mathrm{Zr}$ isotope compositions among different grains. Ibañez-Mejia and Tissot (2019) analyzed the bulk $\mathrm{Zr}$ isotope compositions of zircons and baddeleyites which are cogenetic within the FC-1 anorthositic cumulate. They further reported large $\mathrm{Zr}$ isotopic fractionation in these samples, and show that zircon and baddeleyite were isotopically heavier to the melt, which is contrary to the expectations from bonding rule or results observed by Inglis et al. (2018 and 2019). Recently Feng et al. (2020) presented a new method via thermo-ionization mass-spectrometry (TIMS) and analyzed 11 reference materials including igneous and sedimentary rocks. However, each laboratory has used different reporting standards, hindering easy comparison between the disparate datasets. Given the future interest in in-situ $\mathrm{Zr}$ stable isotopic measurements of zircon and that this method is closely dependent on the zircon standard utilized. It is also important to have the $\mathrm{Zr}$ isotopic composition of zircon standards used for in situ measurements analyzed by wet chemical methods.

In this study, reference materials spanning different bulk compositions and petrogenetic/paragenetic processes have been studied to enhance our understanding of $\mathrm{Zr}$ isotope systematics within different terrestrial reservoirs. In particular, we report the $\mathrm{Zr}$ isotopic composition of 4 widely available zircon standards that had been previously analyzed by laser-ablation (LA)-MC ICPMS, and, tested whether chemical separation of $\mathrm{Zr}$ is necessary prior to analyzing the isotopic composition of individual zircon grains. Furthermore, modified analytical methods have been used to improve the precision, accuracy and efficiency of the technique initially outlined by Inglis et al. (2018). The $\delta^{94 / 90} \mathrm{Zr}_{\text {IPGP-Zr values of igneous rocks spanning a wide compositional range }}$ coupled with bulk measurements of individual zircon grains serves to give a better insight into how $\mathrm{Zr}$ isotopes vary during the magmatic evolution. 
The range of zircons analyzed in Zhang et al. (2019) by LA-MCICPMS were also measured here using a bulk grain, solution method. This technique displays improved analytical precision compared to LA-MCICPMS, albeit with a comprised spatial resolution. Furthermore, all samples analysed as part of previous studies were measured here using the solution double spike MC-ICPMS method in order to better improve the accuracy of $\delta^{94 / 90} \mathrm{Zr}$ values for these samples. These measurements are reinforced by analysis of previously unstudied reference materials, which gives a greater understanding of the $\mathrm{Zr}$ isotope composition of different terrestrial reservoirs.

2. Materials and methods

2.1 Sample materials

In the course of this study, the IPGP-Zr standard solution (Inglis et al., 2018) was used as reporting standard or "zero anchor" for the given delta notation, with the data being reported in delta notation as the ratio in the sample relative to this standard as the permille deviation :

$\delta^{94 / 90} \operatorname{Zr}(\%)=\left(\frac{\left({ }^{94} \mathrm{Zr} /{ }^{90} \mathrm{Zr}\right)_{\text {Sample }}}{\left({ }^{94} \mathrm{Zr} /{ }^{90} \mathrm{Zr}\right)_{I P G P-Z r}}-1\right) \times 1000$

IPGP-Zr standard being the PlasmaCalTM ICP standard (Lot: 5131203028, 2015) solution (Inglis et al. 2018). A total of 26 reference materials were analyzed, including three basalts (BHVO-2 and BIR-1a, United States Geological Survey [USGS] ; BE-N, Centre de Recherches Pétrographiques et Géochimiques, Service d'Analyses des Roches et des Minéraux [CRPG]), one andesite (AGV-2, USGS), three microgabbros (W-2a, USGS; PM-S and WS-E, CRPG), one trachyte (MDO-G; trachyte), one granodiorite (GSP-2, USGS); one syenite (STM-2; USGS), four granites (GH, AC-E GS-N and GA; CRPG); one rhyolite (RGM-1, USGS); one serpentinite (UB-N,USGS); three clastic sediments (JLk-1, JSd-1 and JSd-2; GSJ); one ferro-manganese nodule (Nod-A-1, USGS); one shale (SCo-1,USGS), one bauxite ore (BX-N), and four widely used zircon grains: Penglai (Li et al., 2010; Li et al., 2017), 91500 (Wiedenbeck et al., 1995; Wiedenbeck et al., 2004), GJ-1 (Liu et al., 2010; Morel et al., 2008) and Mud 
Tank (Gain et al., 2019; Yuan et al., 2008). Among them, seven magmatic rocks and six sediments/sedimentary rocks are reported for $\mathrm{Zr}$ isotope compositions for the first time. In addition to the reference materials, two pure $\mathrm{Zr}$ standard solutions used in previous publications were also measured repeatedly as an unknown relative to the IPGP-Zr standard solution. These standard solutions are: SRM3169 (lot: 130920) used in Feng et al. (2020) and an aliquot of the " $\mathrm{Zr}_{\mathrm{NIST}}$ " standard used in Ibañez-Mejia and Tissot (2019). However, there is presently not commercialized isotopically certified $\mathrm{Zr}$

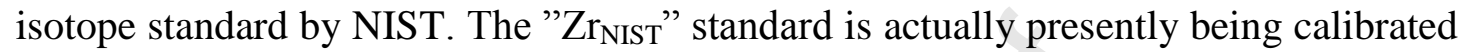
but since it will certainly be widely used in the future, and it had been previously used in one publication, it is beneficial to report its isotopic composition relatively to the IPGP-Zr standard. This solution will be later referred as NIST.

The powdered rock reference materials were weighed in order to give a minimum of $1 \mu \mathrm{g}$ sample $\mathrm{Zr}$ and then spiked with a ${ }^{91} \mathrm{Zr}-{ }^{96} \mathrm{Zr}$ double-spike $\left(51.4 \%{ }^{91} \mathrm{Zr}\right.$ and $48.6 \%{ }^{96} \mathrm{Zr}$ ) at an optimal spike to sample ratio of 43:57 prior to sample digestion (Inglis et al., 2018). Zircon grains were crushed in an agate mortar and left unspiked during the digestion procedure. The sample powders were digested in acid digestion vessel obtained from Parr Instruments ${ }^{\circledR}$ (typically referred to as Parr bombs) using a mixture of concentrated $\mathrm{HF}(\sim 27 \mathrm{M})$ and $\mathrm{HNO}_{3}(\sim 16 \mathrm{M})$ at a $3: 1(\mathrm{v} / \mathrm{v})$ or $8: 1(\mathrm{v} / \mathrm{v})$ (for zircons) ratio to obtain total decomposition of refractory phases. A detailed description of the use of the vessels can be found in Navarro et al. (2008) and Inglis et al. (2018). Following the initial decomposition in the Parr bombs the samples were dried down and treated with $2 \mathrm{~mL} 6 \mathrm{M} \mathrm{HCl}$ at $140{ }^{\circ} \mathrm{C}$ for one day, evaporated to dryness and further treated in $2 \mathrm{~mL}$ mixture of $\mathrm{HCl}(\sim 6 \mathrm{M})$ and $\mathrm{HNO}_{3}(\sim 16 \mathrm{M})$ at a $3: 1(\mathrm{v} / \mathrm{v})$ ratio at $120^{\circ} \mathrm{C}$ for one day. After this the solutions were checked for visual clarity to ensure total decomposition of the sample had been achieved.

\subsection{Chemical separation}


To test whether it is necessary to perform a chemical purification on zircons, spiked zircon solutions with and without chromatographic purification are analyzed. An extended two-step ion-exchange chromatography based on that described by Inglis et al. (2018) was used to purify $\mathrm{Zr}$ from matrix elements (see Table S1). Briefly, in the first column packed with $2 \mathrm{~mL}$ anion exchange resin (Bio-Rad AG1-X8 200-400 mesh), and the sample added to the column in 4M HF. The matrix was eluted with 32 $\mathrm{mL}(4 \times 8 \mathrm{~mL})$ of $4 \mathrm{M} \mathrm{HF}$, apart from $\mathrm{Hf}$, Ti, Mo, Te and $\mathrm{W}$ which remain on the resin along with Zr (Schönbächler et al., 2004). The remaining Zr, Hf and Ti were collected using $10 \mathrm{~mL} 6 \mathrm{M} \mathrm{HCl}+0.01 \mathrm{M} \mathrm{HF}$. After being evaporated to dryness, the samples were treated with $16 \mathrm{M} \mathrm{HNO}_{3}$ and dried to remove the remaining $\mathrm{HCl}$ which would compromise the effect of the next DGA column. For this second stage column, samples were loaded on $1 \mathrm{~mL}$ Eichrom DGA resin in $1 \mathrm{~mL}$ of $12 \mathrm{M} \mathrm{HNO}_{3}$. Remaining matrices such as $\mathrm{Ca}, \mathrm{Fe}$, Ti and Mo were eluted with $12 \mathrm{~mL}$ of $12 \mathrm{M} \mathrm{HNO}_{3}$ and $12 \mathrm{~mL} 3 \mathrm{M} \mathrm{HNO}_{3}$ in sequence. Following this the $\mathrm{Zr}$ was eluted from the column in $10 \mathrm{~mL} 3 \mathrm{M} \mathrm{HNO}_{3}+$ 0.2M HF. This method functions well for terrestrial reference materials and the recovery yields of $\mathrm{Zr}$ were higher than $90 \%$.

After purification, sample solutions were dried down and then treated with concentrated $(16 \mathrm{M}) \mathrm{HNO}_{3}$ at $120^{\circ} \mathrm{C}$ for 2 hours to remove any organic residues eluted from the resin. Following this the sample was dried down and redissolved in $0.5 \mathrm{M}$ $\mathrm{HNO}_{3}+0.1 \mathrm{M} \mathrm{HF}$ prior to mass spectrometry. Full procedural blank was $<1 \mathrm{ng}$.

\subsection{Mass spectrometry protocols}

Zirconium isotope measurements were performed on a Thermo Scientific Neptune Plus MC-ICP-MS at the Institut de Physique du Globe de Paris (IPGP), France. Zirconium, like other HFSE, tends to hydrolyze, resulting in insoluble compounds in solution (Tanaka et al., 2003). To stabilize the $\mathrm{Zr}$ in solution and thus improve analyte washout, $\mathrm{HF}$ was added to the $\mathrm{HNO}_{3}$ carrier solute. Because $\mathrm{HF}$ acid reacts readily with silica as a double displacement reaction, it is problematic to use a quartz spray chamber 
and plasma torch injector assembly as is standard on the Neptune MC-ICPMS. Consequently, an inert (silica free) sample introduction system is required. Here we use a commercially available Savillex ${ }^{\mathrm{TM}}$ PFA cyclonic spray chamber (CSC) (no surface treatment, part number 820-01) (Figure 1a) and a sapphire torch injector (Savillex ${ }^{\mathrm{TM}}$ 851-011-100708, Figure 1b). The CSC is produced by stretch blow molding technology, having an integral cyclonic shape similar to the traditional shape of quartz cyclonic chambers. In order to efficiently extract the sample aerosol towards the plasma an additional make-up gas is required (Figure 1a). Three tests were performed to examine the effectiveness of HF acid and the inert sample introduction system, these were: 1) PFA CSC with $0.5 \mathrm{M} \mathrm{HNO}_{3}$ as carrier acid, 2) PFA CSC with $0.5 \mathrm{M} \mathrm{HNO}_{3}+$ $0.1 \mathrm{M} \mathrm{HF}$ as carrier acid and 3) quartz SIS with $0.5 \mathrm{M} \mathrm{HNO}_{3}$ as carrier acid. The results of these tests are presented in section 3.1. In addition, an ESI APEX HF desolvating nebulizer (Elemental Scientific Inc., USA) coupled with the sapphire injector, is also used for some sample measurements. The Apex HF consists of a heated PFA cyclonic spray chamber and a Peltier cooled condenser. Sample solution were aspirated via a PFA nebulizer into the heated spray chamber and then the dry aerosol passed to the mass spectrometry, whereas excess solvent aerosol was condensed out by the condenser. Apex HF is one of four available Apex platforms, which allows appearance of $\mathrm{HF}$ acid.

Between individual analyses, two types of rinse acid of $1 \mathrm{M} \mathrm{HNO}_{3}+0.1 \mathrm{M} \mathrm{HF}$ and $0.5 \mathrm{M} \mathrm{HNO}_{3}+0.1 \mathrm{M} \mathrm{HF}$ were conducted in order to wash out $\mathrm{Zr}$ efficiently, until the signal of ${ }^{90} \mathrm{Zr}$ lowered to a typical background value of $\sim 0.3-0.5 \mathrm{mV}$ when using the PFA CSC and $\sim 2-4 \mathrm{mV}$ when using the APEX HF.

The intensities of ${ }^{88} \mathrm{Sr}^{+},{ }^{90} \mathrm{Zr}^{+},{ }^{91} \mathrm{Zr}^{+},{ }^{92} \mathrm{Zr}^{+},{ }^{94} \mathrm{Zr}^{+},{ }^{95} \mathrm{Mo}^{+}$and ${ }^{96} \mathrm{Zr}^{+}$were simultaneously measured in static mode. ${ }^{88} \mathrm{Sr}^{+}$was used to calibrate the ${ }^{91} \mathrm{Zr}^{+}-{ }^{96} \mathrm{Zr}^{+}$ double spike (Inglis et al., 2018), while ${ }^{95} \mathrm{Mo}^{+}$was collected to monitor interferences of ${ }^{94} \mathrm{Mo}^{+}$and ${ }^{96} \mathrm{Mo}^{+}$on ${ }^{94} \mathrm{Zr}^{+}$and ${ }^{96} \mathrm{Zr}^{+}$masses respectively. The instrumental fractionation factor calculated from each $\mathrm{Zr}$ isotope analysis was applied to get the measured ${ }^{94} \mathrm{Mo}^{+}$ 
and ${ }^{96} \mathrm{Mo}^{+}$which could be subtracted from the signals of ${ }^{94} \mathrm{Zr}^{+}$and ${ }^{96} \mathrm{Zr}^{+}$, based on the natural ratios of ${ }^{94} \mathrm{Mo}^{+} /{ }^{95} \mathrm{Mo}^{+}$and ${ }^{96} \mathrm{Mo}^{+} /{ }^{95} \mathrm{Mo}^{+}$were 0.5805 and 1.0491 respectively (de Laeter et al., 2003). The details of the instrumental operating parameters are given in Table S2.

\subsection{Data reduction and notation}

Data acquisition consisted of 1 block of 40 cycles with an individual integration time of 4.194 seconds. Three isotopic ratios are required to solve for the three unknowns - 1) mass-dependent fraction factors of samples relative to the standard, 2) the instrumental fraction factor and, 3) the mass fraction of the denominator isotope contributed from the double spike in the sample-double spike mixture. For this ${ }^{91} \mathrm{Zr}^{+} \rho^{90} \mathrm{Zr}^{+},{ }^{94} \mathrm{Zr}^{+} \rho 0 \mathrm{Zr}^{+}$and ${ }^{96} \mathrm{Zr}^{+} /{ }^{90} \mathrm{Zr}^{+}$were used for double spike data inversion calculation, which is achieved using the Isospike plugin for the software package Iolite (Creech and Paul, 2015).

\section{Results and discussion}

\subsection{Zirconium washouts during measurement}

The washout time for $\mathrm{Zr}$ during nebulization in the introduction system can be long because $\mathrm{Zr}$ has a strong tendency to hydrolyse, producing insoluble compounds. To investigate the benefits of using dilute HF within the analyte carrier acid and rinse acid, tests were performed using the inert PFA CSC and standard quartz SIS with different acids. These were: PFA CSC with $0.5 \mathrm{M} \mathrm{HNO}_{3}, \mathrm{PFA} C \mathrm{CSC}$ with $0.5 \mathrm{M} \mathrm{HNO}+$ $0.1 \mathrm{M} \mathrm{HF}$ and quartz SIS with $0.5 \mathrm{M} \mathrm{HNO}_{3}$. The results of these tests for a $200 \mathrm{ng} \mathrm{mL}^{-1}$ IPGP-Zr solution are shown in Figure 2.

It took $\sim 35$ min when using the two configurations without $\mathrm{HF}$ acid to reduce the intensity to blank level, whereas the PFA CSC with $0.5 \mathrm{M} \mathrm{HNO}_{3}+0.1 \mathrm{M} \mathrm{HF}$ only had a wash out time of $3.5 \mathrm{~min}$, where the signal returned to pre-background intensities. 


\subsection{Chemical purification of zircon grains}

The main cations of zircon $\left(\mathrm{ZrSiO}_{4}\right)$ are $\mathrm{Zr}$ and $\mathrm{Si}$. In addition, zircon is an important host for trace U, Th, Hf and the REE (Hoskin and Schaltegger, 2003). Theoretically, as these trace elements in zircon would not exert any influence on the analyses of $\mathrm{Zr}$ isotope composition on mass spectrometry, it is not necessary to perform chromatographic purification on individual zircon grains. To confirm this, tests were performed for purified and unpurified zircon grains, the results of which are presented in Table 1 and Figure 3. With respect to this, it is apparent that there is no resolvable difference between zircons that have undergone purification chemistry and those that have not. This is consistent with the fact that the main isobaric interfering element on $\mathrm{Zr}$ isotopes is Mo and the ${ }^{95} \mathrm{Mo}^{+} /{ }^{90} \mathrm{Zr}^{+}$ratio was not changed whether we performed chemical purification or not. Therefore, without purifying zircons, accurate $\mathrm{Zr}$ isotope composition would be also measurable.

\subsection{Accuracy and Precision}

Zirconium isotope compositions of the reference materials analyzed in this study show good consistency with literature data from Inglis et al. (2018), including BHVO-2, BIR-1a, AGV-2, GS-N, RGM-1 and UB-N (Figure 6 and Table 3). The exception to this is the granite GA, which is offset towards a lighter isotopic composition in our study. To examine the possible cause of this discrepancy, repeat measurements from two different batches of GA were measured. These replicate measurements yielded average $\delta^{94 / 90} \mathrm{Zr}_{\text {IPGP-Zr }}$ data of $0.100 \pm 0.056 \%$ o $(2 \mathrm{SD}, \mathrm{n}=14)$ and $0.099 \pm 0.047 \%$ o $(2 \mathrm{SD}, \mathrm{n}=16)$ where $\mathrm{n}$ denotes the number of measurements from one batch of powder, which is dissolved and measured at different times. These two batches provide consistent isotopic composition within error but are both different from Inglis et al. (2018) $(0.188 \pm 0.019 \% ; 2 S D, n=4)$. The IPGP inhouse stock of the GA powder used by Inglis et al. (2018) has been exhausted, preventing investigation of sample heterogeneity between the 3 batches of powder. As such, based on our results and of 
Inglis et al. (2018), it is possible that $\mathrm{Zr}$ isotopic heterogeneity does exist within this sample.

Although it is not necessary to propagate the internal errors when using double spike technique, from the point of view of sampling statistics, internal errors indicated by standard error (2se) set the lowest limit of the precision which is usually referred to as the 'external precision' and is indicated by two standard deviation (2SD) based on replicated measurements of the same aliquots. Because the purification chemistry used here removes almost all matrix Mo, with measured intensity of ${ }^{95} \mathrm{Mo}^{+}$typically between $0.01 \mathrm{mV} \sim 0.1 \mathrm{mV}$. As such, the internal errors vary roughly in proportion to the square root of the intensity, providing the amount of analysis cycles remain constant. In addition, increasing of the number of cycles also serves to improve the internal precision, as, statistically, the two standard error is inversely proportional to the square root of the number of measurements. As shown in Figure 4 and Figure 5, measurements made using the Apex introduction system can give an improved signal intensity of roughly 4-fold compared to the PFA CSC. For example, we obtain $\sim 3.3-3.8 \mathrm{~V}$ on ${ }^{90} \mathrm{Zr}^{+}$ at total $\mathrm{Zr}$ concentration of $200 \mathrm{ng} \mathrm{mL}^{-1}$ under low mass resolution $(\mathrm{M} / \Delta \mathrm{M} \approx 1700)$ and at an aspirating rate of $50 \mu \mathrm{l} / \mathrm{min}$ using the CSC system. Under the same measurement condition, using an Apex HF we obtained $\sim 12-14 \mathrm{~V}$ on ${ }^{90} \mathrm{Zr}^{+}$. The internal error denoted by two standard errors (2se) within one analysis improved from 0.033 $0.035 \%$ using the CSC to $0.015 \sim 0.018 \%$ o using Apex when the number of cycles is 40 . Furthermore, a greater number of analyses give improved internal precision as mentioned above. Typically, the 2 se could reach around $0.011 \%$ for 100 cycles. This improvement of the internal precision logically implies an improvement of the external precision (2SD).

\subsection{Cross calibration of existing Zr standards}

To date there are only six studies that present stable $\mathrm{Zr}$ isotopic mass dependent variations within natural samples. Akram and Schönbächler (2016) firstly reported Zr 
stable isotope variations between pure Zr standard solution: NIST SRM 3169, a VWR standard solution and and Alfa Aesar solution lot \#71-070882. Since we have no standard solution in common with this study it is not possible to directly compare our data or include these standards within our study. In the previous $\mathrm{Zr}$ isotopic studies, four different reference standards have been used : IPGP-Zr (Inglis et al., 2018; 2019), GJ-1 (Zhang et al., 2019), $\mathrm{Zr}_{\mathrm{NIST}}$ (Ibañ ez-Mejia and Tissot, 2019) (the name of which is now NIST) and SRM3169 (Feng et al., 2020). This is problematic as it prevents easy comparison of the disparate datasets. It should be noted that Feng et al. (2020) already analyzed the IPGP-Zr standard against SRM3169. In order to remedy to this, we have measured GJ-1, SRM3169 and NIST Zr standards used in these existing publications, relative to the IPGP-Zr standard.

As shown in Table 2 and Figure 4, the offsets of the $\delta^{94 / 90} \mathrm{Zr}$ between the four standard solutions are small, less than $33 \mathrm{ppm}$ between the three solutions. The variations between these solutions are an order of magnitude smaller than between the three standard solutions analyzed by Akram and Schönbächler (2016). The averaged $\delta^{94 / 90} \mathrm{Zr}_{\mathrm{IPGP}-\mathrm{Zr}}$ of three replicates of GJ-1 is $-0.008 \pm 0.022 \%$ ( $\left.2 \mathrm{SD}, \mathrm{n}=12\right)$. The average $\delta^{94 / 90} \mathrm{Zr}_{\text {IPGP-Zr }}$ of SRM3169 $(0.026 \pm 0.028 \%$, 2SD, $\mathrm{n}=16)$ agrees with the difference reported in Feng et al. (2020) $(0.04 \pm 0.06 \%$, 2SD, $\mathrm{n}=16)$. The $\delta^{94 / 90} \mathrm{Zr}_{\text {IPGP-Zr }}$ of SRM3169 is further calibrated via combining our results with Feng et al. (2020) to get a value of $0.033 \pm 0.033 \%$ ( $2 \mathrm{SD})$ where the $2 \mathrm{SD}$ is propagated from the two individual errors. The $\delta^{94 / 90} \mathrm{Zr}_{\text {IPGP-Zr values of NIST is } 0.033 \pm 0.042 \% \text { ( }}$ (2SD, $\left.\mathrm{n}=18\right)$. Based on these results we suggest the following offset values can be applied to samples measured relative to SRM3169 of $0.033 \pm 0.033 \%$ (2SD), NIST of $0.033 \pm 0.042 \%$ (2SD) and GJ-1 of $-0.008 \pm 0.022 \%$ in order to present final delta values relative to IPGP-Zr. This serves to allow for the easy comparison of $\mathrm{Zr}$ isotope values between studies.

Figure 6 displays $\delta^{94 / 90} \mathrm{Zr}_{\text {IPGP-Zr }}$ values of the reference materials studied here compared to literature data for the same reference materials. Values for five zircons and four igneous rocks previously analyzed at IPGP and China University of Geosciences 
(CUG) are also given. For comparison data given by Zhang et al. (2019), which was obtained using an in situ LA-MC-ICP-MS technique, has been renormalized to the IPGP-Zr standard and presented as $\delta^{94 / 90} \mathrm{Zr}_{\text {IPGP-Zr }}$ using an offset value of $-0.008 \pm 0.022$ $\%$ o $(2 \mathrm{SD} ; \mathrm{n}=12)$ which is the difference that we obtained between the zircon standard used in this study (GJ-1) and the IPGP-Zr standard. It should be noted that all the replicates of the zircons in this study are from different parts of one single crystal. The consistency of $\delta^{94 / 90} \mathrm{Zr}_{\text {IPGP-Zr }}$ values of the replicates from this study and the consistency of zircon data between the two laboratories confirms the accuracy of both wet-chemistry and in-situ analysis for $\mathrm{Zr}$ isotope measurements. Furthermore, it shows that these zircons could be used as homogenous $\mathrm{Zr}$ isotopic references, which is not the case for the FC-1 zircon which are very heterogeneous (see Zhang et al. 2019). In terms

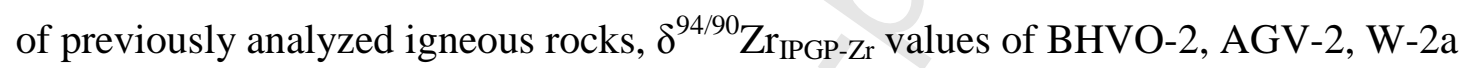
and GSP-2 are consistent within error albeit slightly heavier with what was reported in Feng et al. (2020).

\subsection{The stable $\mathrm{Zr}$ isotopic composition of geological reference materials}

The stable $\mathrm{Zr}$ isotope compositions of all reference materials analyzed in this study and complementary literature data are presented in Table 3 and displayed in Figure 3..The samples noted "Replicate" represents full replicated measurements, including different dissolutions, double spike additions, chemical separations and mass spectrometer measurements. When nothing is indicated it means that these are the same solutions that have been analysed during different mass-spectrometry sessions. For example, we have performed 8 full replicates of BHVO-2 (for 45 mass-spectrometry analyses total) which are all identical within error with the most extreme values being $0.025 \pm 0.067 \%$ o and $0.061 \pm 0.041 \%$ for an average of $0.044 \pm 0.041 \%$.

The overall $\delta^{94 / 90} \mathrm{Zr}_{\text {IPGP-Zr }}$ range of the reference materials analyzed in this study is $0.602 \%$, indicating large $\mathrm{Zr}$ isotope variation both high and low-temperature geological processes. 
We report the first $\mathrm{Zr}$ isotopic data for sedimentary rocks. We can note that most sedimentary rocks have isotopic composition that fall within the range of igneous rocks at the exception of the manganese nodule Nod1-A $(-0.127 \pm 0.024)$ suggesting either isotopically light seawater and/or isotopic fractionation of $\mathrm{Zr}$ during adsorption processes. More work will be needed to further tests these hypotheses. The serpentinite, UB-N, have similar isotopic composition as basalts suggesting that serpentinization has a limited effect on $\mathrm{Zr}$ isotopes at the bulk rock scale. This is not surprising given that $\mathrm{Zr}$ is among the less mobile elements during low $P-T$ aqueous fluid alteration processes (Anderson et al., 2002; Green et al., 2006).

The igneous rocks span a compositional range from mafic to felsic. Across this range an increase of $\mathrm{Zr}$ isotope compositions towards heavier values in observed for more evolved (felsic) rocks. Although these rocks are not genetically related, this trend is consistent with previous work that has shown felsic rocks to be preferentially enriched in the heavier isotopes of $\mathrm{Zr}$, which is interpreted to reflect incorporation of the lighter isotopes within zircons owing to differences in coordination chemistry (Inglis et al., 2018, 2019).

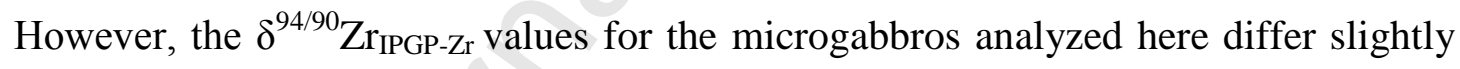
from this simple interpretation. The $\delta^{94 / 90} \mathrm{Zr}_{\text {IPGP-Zr }}$ of microgabbros range from isotopically light (PM-S: $-0.103 \pm 0.050 \%$ o $2 \mathrm{SD}$ ) to heavy (W-2a: $0.112 \pm 0.040 \%$ 2SD) isotopic composition compared to basalts, within which one value (WS-E: 0.036 0.049\%o) accords with that of the basalts. Within the main Zr-bearing phases, zircon and baddeleyite, the coordination number $(\mathrm{CN})$ for $\mathrm{Zr}$ are eight and seven respectively. Whereas $\mathrm{Zr}$ exists in 6-fold in silicate melts. Apart from zircon and baddeleyite, clinopyroxene is also an important host for $\mathrm{Zr}$ (Watson and Ryerson 1986; Krogh 1993). Zirconium usually occurs in six-folded sites of clinopyroxenes (Wilke et al., 2019). In addition, $\mathrm{Zr}$ could substitute for $\mathrm{Ti}$ in the 6-fold coordinated Ti oxide minerals (Farges et al., 1991; Louvel et al., 2013). Thus, zircon and baddeleyite should preserve lighter $\mathrm{Zr}$ isotpes compared to the melts whereas the isotopic effects induced by 
clinopyroxene or Ti oxide minerals are unclear if just based on coordination chemistry. The limited information about the occurrence of zircon or baddeleyite in these microgabbros makes it difficult to explain the variations. Without further mineral-scale $\mathrm{Zr}$ isotope investigations including clinopyroxene and Ti oxides, and the knowledge of zircon or baddeleyite features in these microgabbros, it is difficult to comment on their Zr isotopic composition.

The range of $\delta^{94 / 90} \mathrm{Zr}_{\text {IPGP-Zr }}$ values seen in 5 zircon reference grains (the four reported here plus Plešovice zircon from Inglis et al. 2018), are resolvably different, with an overall variation of $\sim 0.20 \%$. Of these grains Penglai has the lowest $\delta^{94 / 90} \mathrm{Zr}_{\text {IPGP-Zr }}$ (average of $-0.094 \pm 0.043 \%$ ) whereas Plešovice exhibit the highest value $(0.113 \pm$

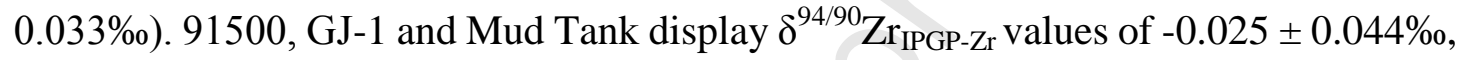
$-0.008 \pm 0.022 \%$ and $0.059 \pm 0.040 \%$ respectively. The $\mathrm{Zr}$ isotope composition of zircons depends on many factors. Zircons can have various origins, including igneous and metamorphic petro/para-genesis (Belousova et al., 1998; Corfu et al., 2003; Hoskin and Schaltegger, 2003; Nasdala et al., 2001). For example, the Penglai zircon megacrysts originated from Neogene alkaline basalts (Li et al., 2010; Li et al., 2017) whereas the Plešovice zircon occurred in a potassic granulite (Vrána, 1989). Three zircons from magmatic origins $(-0.094 \pm 0.043 \%$ to $-0.008 \pm 0.022 \%$ ) are significantly lighter than the estimated mantle composition based on basalts $(0.048 \pm 0.032 \%$; 2 sd, $n=48$, Inglis et al. 2018) and most magmatic rocks presented here. Based purely on coordination chemistry, zircons should have a lighter $\mathrm{Zr}$ isotopes compared to their equilibrated melts (see Inglis et al. 2019) and therefore our observation is in agreement with this prediction. Mud Tank zircons originated from a magmatic carbonatitic rock, however, it is possible that zircons from carbonatites suffered recrystallization because of infiltration of late-stage melt (Tichomirowa et al. 2013). For the metamorphic related zircon from metamorphic rocks, their formation could originate from melting during anatexis (Vavra et al., 1999), decomposition of different minerals (such as garnet, feldspar, rutile) (Fraser et al., 1997), or 
metamorphic fluid (Dubińska et al., 2004), all processes that could create $\mathrm{Zr}$ various isotopic fractionations and therefore explain the different isotopic composition of the zircon from Plešovice from magmatic zircons. Mineral-scale studies of zircons (e.g. Zhang et al. 2019) will be the key in the future to better understand fractionation mechanism of $\mathrm{Zr}$ isotopes in different geological processes - particularly those forming in metamorphic environments.

\section{Conclusions}

The stable $\mathrm{Zr}$ isotope compositions of 26 widely available reference materials, including 4 zircons previously used for in-situ analyses, and 3 standard solutions previously used as reference standards for bulk measurements, were analyzed in this study.

The overall variation of $\delta^{94 / 90} \mathrm{Zr}_{\text {IPGP-Zr }}$ between the reference materials is $0.602 \%$, indicating significant $\mathrm{Zr}$ isotopic composition in nature. The value reported here for zircon standard are consistent with previously measured by LA-MCICPMS. Interlaboratory comparisons demonstrate the accuracy of the method used in this study, especially from the zircon results. We show that for the analysis of zircons, there is no need to perform prior chemical purification to obtain high precision isotopic data. Magmatic zircons have light isotopic compositions compared to basalts, as inferred previously based on the isotopic composition of a magmatic differentiation series.

We report the offsets between the three different standards used previously in the literature. These values can be used in future works for inter-laboratory comparisons. In general, $\delta^{94 / 90} \mathrm{Zr}_{\text {IPGP-Zr values become higher as the magmatic composition is more }}$ evolved. The relatively large variations of $\delta^{94 / 90} \mathrm{Zr}_{\text {IPGP-Zr }}$ values between intrusive igneous rocks likely reflect mineral accumulation or crystallization and mineral-melt segregation. The trend of $\mathrm{Zr}$ isotope fractionation between mineral and silicate melt accords with empirical bonding rules and the observation from Inglis et al (2019). 


\section{Acknowledgements}

We thank R. Mathur, M. Schönbächler and an anonymous reviewer for thorough reviews and helpful comments that have improved the quality of the manuscript. We also thank B. Kamber for very efficient editorial handling.

Pascale Louvat, Thibaut Sontag and Pierre Burckel are thanked for technical support of the (MC-)ICP-MS at IPGP. Lanping Feng, Mauricio Ibanez-Mejia and Francois Tissot are thanked for providing the $\mathrm{Zr}$ pure solutions. SYT is grateful to China Scholarship Council fellowship. This work was supported by the ERC under the European Community's H2020 framework program/ERC grant agreement No. 637503 (Pristine) awarded to FM. Additional support from the UnivEarthS Labex program (numbers: ANR-10-LABX- 0023 and ANR-11-IDEX-0005-02). Parts of this work were supported by IPGP multidisciplinary program PARI, and by Region île-de-France SESAME Grant (no. 12015908).

\section{References}

Akram, W., Schönbächler, M., 2016. Zirconium isotope constraints on the composition of Theia and current Moon-forming theories. Earth Plane. Sci. Lett. 449: 302-310.

Akram, W., Schönbächler, M., Bisterzo, S., Gallino, R., 2015. Zirconium isotope evidence for the heterogeneous distribution of s-process materials in the solar system. Geochim. Cosmochim. Acta 165: 484-500.

Anderson, S.P., Dietrich, W.E., Brimhall Jr, G.H., 2002. Weathering profiles, mass-balance analysis, and rates of solute loss: Linkages between weathering and 
erosion in a small, steep catchment. Geol. Soc. Am. Bull. 114: 1143-1158.

Belousova, E.A., Griffin, W.L., Pearson, N.J., 1998. Trace element composition and cathodoluminescence properties of southern African kimberlitic zircons. Mineral. Mag. 62: 355-366.

Bonnand, P., Williams, H.M., Parkinson, I.J., Wood, B.J., Halliday, A.N., 2016. Stable chromium isotopic composition of meteorites and metal-silicate experiments: Implications for fractionation during core formation. Earth Plane. Sci. Lett. 435: 14-21.

Chauvel C., Bureau S., Poggi C., 2011. Comprehensive Chemical and Isotopic Analyses of Basalt and Sediment Reference Materials. Geostand. Geoanal. Res. $35: 125-143$.

Condie, K.C., Shearer, C.K., 2017. Tracking the evolution of mantle sources with incompatible element ratios in stagnant-lid and plate-tectonic planets. Geochim. Cosmochim. Acta 213: 47-62.

Corfu, F., Hanchar, J.M., Hoskin, P.W., Kinny, P., 2003. Atlas of zircon textures. Rev. Mineral. Geochem. 53: 469-500.

Creech, J.B., Paul, B., 2015. IsoSpike: Improved Double-Spike Inversion Software. Geostand. Geoanal. Res. 39: 7-15.

Dauphas, N., Roskosz, M., Alp, E. E., Neuville, D. R., Hu, M. Y., Sio, C. K., Tissot, F. L. H., Zhao, J., Tissandier, L., Médard, E., Cordier, C., 2014.Magma redox and structural controls on iron isotope variations in Earth's mantle and crust. Earth 
Plane. Sci. Lett. 398: 127-140.

de Laeter, J.R., Böhlke, J.K., De Bièvre, P., Hidaka, H., Peiser, H. S., Rosman, K.

J. R., Taylor, P. D. P., 2003. Atomic weights of the elements. Review 2000 (IUPAC Technical Report). Pure Appl. Chem. 75: 683-900.

Deng, Z.B., Chaussidon, M., Savage, P., Robert, F., Pik, R., Moynier, F., 2019.

Titanium isotopes as a tracer for the plume or island arc affinity of felsic rocks. Proc.

Natl. Acad. Sci. 116: 1132-1135.

Deng, Z.B., Moynier, F., van Zuilen, K., Sossi, P. A., Pringle, E.A., Chaussidon, M., 2018. Lack of resolvable titanium stable isotopic variations in bulk chondrites. Geochim. Cosmochim. Acta 239: 409-419.

Dubińska, E., Bylina, P., Kozłowski, A., Dörr, W., Nejbert, K., Schastok, J., Kulicki, C., 2004. U-Pb dating of serpentinization: hydrothermal zircon from a metasomatic rodingite shell (Sudetic ophiolite, SW Poland). Chem. Geol. 203: 183-203.

Farges, F., Ponader, C.W., Brown Jr, G.E., 1991. Structural environments of incompatible elements in silicate glass/melt systems: I. Zirconium at trace levels. Geochim. Cosmochim. Acta 55: 1563-1574.

Feng, L.P., Hu W.F., Jiao Y., Zhou L., Zhang W., Hu Z.C., Liu Y.S., 2020. High-precision stable zirconium isotope ratio measurements by double spike thermal ionization mass spectrometry. J. Anal. At. Spectrom. 35: 736-745.

Fraser, G., Ellis, D., Eggins, S., 1997. Zirconium abundance in granulite-facies 
minerals, with implications for zircon geochronology in high-grade rocks. Geology, 25(7): 607-610.

Gain, S.E., Gréau, Y., Henry, H., Belousova, E., Dainis, I., Griffin, W., O'reilly, S., 2019. Mud Tank Zircon: Long- term Evaluation of a Reference Material for U- $\mathrm{Pb}$ Dating, Hf- Isotope analysis and trace element analysis. Geostand. Geoanal. Res. 156: $35-43$.

Greber, N.D., Dauphas, N., Puchtel, I.S., Hofmann, B.A., Arndt, N.T., 2017. Titanium stable isotopic variations in chondrites, achondrites and lunar rocks. Geochim. Cosmochim. Acta 213: 534-552.

Green, E.G., Dietrich, W.E., Banfield, J.F., 2006. Quantification of chemical weathering rates across an actively eroding hillslope. Earth Plane. Sci. Lett. 242: 155-169.

Hanchar, J.M., Watson, E.B., 2003. Zircon Saturation Thermometry. Rev. Mineral. Geochem. 53: 89-112.

Hart, S.R., Dunn, T., 1993. Experimental cpx/melt partitioning of 24 trace elements. Contrib. Mineral. Petrol. 113: 1-8.

Hoskin, P.W., Schaltegger, U., 2003. The composition of zircon and igneous and metamorphic petrogenesis. Rev. Mineral. and Geochem. 53: 27-62.

Ibañez-Mejia, M., Tissot, F.L., 2019. Extreme Zr stable isotope fractionation during magmatic fractional crystallization. Sci. Adv. 5: eaax8648.

Iizuka, T., Lai, Y.-J., Akram, W., Amelin, Y., Schönbächler, M., 2016. The initial 
abundance and distribution of $92 \mathrm{Nb}$ in the Solar System. Earth Plane. Sci. Lett. 439: $172-181$.

Inglis, E.C., Creech, J.B., Deng, Z.B., Moynier, F., 2018. High-precision zirconium stable isotope measurements of geological reference materials as measured by double-spike MC-ICPMS. Chem. Geol. 493: 544-552.

Inglis, E.C., Moynier, F., Creech, J., Deng, Z. B., Day, J.M.D., Teng, F.Z., Bizzarro, M., Jackson, M., Savage, P., 2019. Isotopic fractionation of zirconium during magmatic differentiation and the stable isotope composition of the silicate Earth. Geochim. Cosmochim. Acta 250: 311-323.

Jaakko, S., 1977. Baddelyite- $\mathrm{ZrO}_{2}$-from Lovasjärvi diabase, southeastern Finland. Bull. Geol. Soc. Finl. 49: 59-64.

Kang, J.T., Ionov, D., Liu, F., Zhang, C.L., Golovin, A.V., Qin, L.P., Zhang, Z.F., Huang, F., 2017. Calcium isotopic fractionation in mantle peridotites by melting and metasomatism and $\mathrm{Ca}$ isotope composition of the Bulk Silicate. Earth. Earth Plane. Sci. Lett. 474: 128-137.

Kato, C., Moynier, F., 2017. Gallium isotopic evidence for extensive volatile loss from the Moon during its formation. Sci. Adv. 3(7): e1700571.

Krogh, T.E., 1993. High precision U-Pb ages for granulite metamorphism and deformation in the Archean Kapuskasing structural zone, Ontario: implications for the structure and development of the lower crust. Earth and Planet. Sci. Lett. 119, 1-18.

Li, X.H., Long, W.G., Li, Q.L., Liu, Y., Zheng, Y.F., Yang, Y.H, Chamberlain, 
K.R., Wan, D.F., Guo, C. H, Wang, X.C., 2010. Penglai zircon megacrysts: a potential new working reference material for microbeam determination of $\mathrm{Hf}-\mathrm{O}$ isotopes and $\mathrm{U}-\mathrm{Pb}$ age. Geostand. Geoanal. Res. 34: 117-134.

Li, Y.J., Zheng, D.W., Wu, Y., Wang, Y., He, H.Y., Pang, J.Z., Wang, Y.Z., Yu, J.X., 2017. A Potential (U-Th)/He Zircon Reference Material from Penglai Zircon Megacrysts. Geostand. Geoanal. Res. 41: 359-365.

Liu, Y.S., Hu, Z.C., Zong, K.Q., Gao, C.G., Gao, S., Xu, J., Chen, H.H., 2010. Reappraisement and refinement of zircon $\mathrm{U}-\mathrm{Pb}$ isotope and trace element analyses by LA-ICP-MS. Chin. Sci. Bull., 55: 1535-1546.

Lodders, K., 2003. Solar System Abundances and Condensation Temperatures of the Elements. Astrophys. J. 591: 1220-1247.

Louvel, M., Sanchez-Valle, C., Malfait, W.J., Testemale, D., Hazemann, J.-L., 2013. Zr complexation in high pressure fluids and silicate melts and implications for the mobilization of HFSE in subduction zones. Geochim. Cosmochim. Acta 104: 281-299.

Mallmann, G., O’Neill, H.S.C., 2009. The crystal/melt partitioning of V during mantle melting as a function of oxygen fugacity compared with some other elements (Al, P, Ca, Sc, Ti, Cr, Fe, Ga, Y, Zr and Nb). J. Petrol. 50: 1765-1794.

Marks, M., Halama, R., Wenzel, T., Markl, G., 2004. Trace element variations in clinopyroxene and amphibole from alkaline to peralkaline syenites and granites: implications for mineral-melt trace-element partitioning. Chem. Geol. 211: 185-215. 
McDade, P., Blundy, J.D., Wood, B.J., 2003. Trace element partitioning on the Tinaquillo Lherzolite solidus at 1.5 GPa. Phys. Earth Planet. Inter. 139: 129-147.

Millet, M.-A., Dauphas, N., Greber, N.D., Burton, K.W., Dale, C.W., Debret, B., Macpherson, C.G., Nowell, G.M., Williams, H.M., 2016. Titanium stable isotope investigation of magmatic processes on the Earth and Moon. Earth Plane. Sci. Lett. 449: 197-205.

Milnes, A., Fitzpatrick, R.W., 1989. Titanium and zirconium minerals, in Dixon, J. B., Weed S. B.(Eds), Minerals in soil environments, $2^{\text {nd }}$ Edition. Soil Science Society of America, Madison, Wisconsin, pp: 1131-1205.

Morel, M., Nebel, O., Nebel-Jacobsen, Y., Miller, J., Vroon, P., 2008. Hafnium isotope characterization of the GJ-1 zircon reference material by solution and laser-ablation MC-ICPMS. Chem. Geol. 255: 231-235.

Nasdala, L. Wenzel, M., Vavra, G., Irmer, G., Wenzel, T., Kober, Bernd., 2001. Metamictisation of natural zircon: accumulation versus thermal annealing of radioactivity-induced damage. Contrib. Mineral. Petrol. 141: 125-144.

Navarro, M.S., Andrade, S., Ulbrich, H., Gomes, C.B., Girardi, V.A.V., 2008. The Direct Determination of Rare Earth Elements in Basaltic and Related Rocks using ICP-MS: Testing the Efficiency of Microwave Oven Sample Decomposition Procedures. Geostand. Geoanal. Res. 32: 167-180.

Niu, Y.L., 2004. Bulk-rock Major and Trace Element Compositions of Abyssal Peridotites: Implications for Mantle Melting, Melt Extraction and Post-melting 
Processes Beneath Mid-Ocean Ridges. J. Petrol. 45: 2423-2458.

Palme, H., O'Neill, H.S.C., 2003. Cosmochemical estimates of mantle composition, in Treatise Geochem., vol. 2, R.W. Carlson Ed., Elsevier-Pergamon, Oxford, pp. 568-607

Pearce, J.A., Parkinson, I.J., 1993. Trace element models for mantle melting: application to volcanic arc petrogenesis. Geo. Soc. London Special Pub. 76: 373-403.

Salters, V.J.M., Shimizu, N., 1988. World-wide occurrence of HFSE-depleted mantle. Geochim.Cosmochim. Acta 52: 2177-2182.

Schauble, E.A., 2004. Applying stable isotope fractionation theory to new systems. Rev. Mineral. Geochem. 55: 65-111.

Schönbächler, M., Lee, D-C., Rehkämper, M., Halliday, A.N., Fehr, M.A., Hattendorf, B., Günther, D. 2003. Zirconium isotope evidence for incomplete admixing of r-process components in the solar nebula. Earth Plane. Sci. Lett. 216: 467-481.

Schönbächler, M., Rehkämper, M., Halliday, A.N., Lee, D-C., Bourot-Denise, M., Zanda, B., Hattendorf, B., Günther, D., 2002. Niobium-Zirconium Chronometry and Early Solar System Development. Science 295: 1705-1708.

Schönbächler, M., Rehkämper, M., Lee, D.-C., Halliday, A.N., 2004. Ion exchange chromatography and high precision isotopic measurements of zirconium by MC-ICP-MS. Analyst 129: 32-37.

Tanaka, R., Makishima, A., Kitagawa, H., Nakamura, E., 2003. Suppression of 
$\mathrm{Zr}, \mathrm{Nb}, \mathrm{Hf}$ and Ta coprecipitation in fluoride compounds for determination in Ca-rich materials. J. Anal. At. Spectrom. 18: 1458-1463.

Tichomirowa, M., Whitehouse’ M, Gerdes' A., Götze’J., Schulz’B., Belyatsky, B. Different zircon recrystallization types in carbonatites caused by magma mixing: Evidence from $\mathrm{U}-\mathrm{Pb}$ dating, trace element and isotope composition ( $\mathrm{Hf}$ and $\mathrm{O}$ ) of zircons from two Precambrian carbonatites from Fennoscandia. Chem. Geol. 353, 173-178.

Vavra, G., Schmid, R., Gebauer, D., 1999. Internal morphology, habit and $\mathrm{U}-\mathrm{Th}-\mathrm{Pb}$ microanalysis of amphibolite-to-granulite facies zircons: geochronology of the Ivrea Zone (Southern Alps). Contrib. Mineral. Petrol. 134: 380-404.

Vrána, S., 1989. Perpotassic granulites from southern Bohemia. Contrib. Mineral. Petrol. 103: 510-522.

Wang, Z.Z., Liu, S.A., Liu, J.G., Huang, J., Xiao, Y., Chu, Z.Y., Zhao, X.M., Tang, L.M., 2017. Zinc isotope fractionation during mantle melting and constraints on the $\mathrm{Zn}$ isotope composition of Earth's upper mantle. Geochim.Cosmochim. Acta 198: $151-167$.

Watson, E.B., Ryerson, F., 1986. Partitioning of zirconium between clinopyroxene and magmatic liquids of intermediate composition. Geochim.Cosmochim. Acta 50: 2523-2526.

Weyer, S., Münker, C., Mezger, K., 2003. Nb/Ta, Zr/Hf and REE in the depleted mantle: implications for the differentiation history of the crust-mantle system. Earth Plane. Sci. Lett., 205: 309-324. 
Wiedenbeck, M., Alle, P., Corfu, F., Griffin, W.L., Meier, M., Oberli, F., Quadt, A.Von, Roddick, J.C., Spiegel, W., 1995. Three natural zircon standards for U- Th$\mathrm{Pb}, \mathrm{Lu}-\mathrm{Hf}$, trace element and REE analyses. Geostand. Newslett. 19: 1-23.

Wiedenbeck, M., Hanchar, J.M., Peck, W.H., Sylvester, P., Valley, J., Whitehouse, M., Kronz, A., Morishita, Y., Nasdala, L., Fiebig, J., 2004. Further characterisation of the 91500 zircon crystal. Geostand. Geoanal. Res. 28: 9-39.

Wilke, M., Stix, J., van Hinsberg, V.J., Beard, C.D., 2019. Clinopyroxene/Melt Trace Element Partitioning in Sodic Alkaline Magmas. J. Petrol., 60: 1797-1823.

Woodhead, J., Eggins, S., Gamble, J., 1993. High field strength and transition element systematics in island arc and back-arc basin basalts: evidence for multi-phase melt extraction and a depleted mantle wedge. Earth Plane. Sci. Lett. 114: 491-504.

Yuan, H.L., Gao, S., Dai, M.N., Zong, C.L., Günther, D., Fontaine, G.H., Liu, X.M., Diwu, C.R., 2008. Simultaneous determinations of U-Pb age, Hf isotopes and trace element compositions of zircon by excimer laser-ablation quadrupole and multiple-collector ICP-MS. Chem. Geol. 247: 100-118.

Zhang, S.H., Zhao, Y., Yang, Z.Y., He, Z.F., Wu, H., 2009. The 1.35 Ga diabase sills from the northern North China Craton: implications for breakup of the Columbia (Nuna) supercontinent. Earth Plane. Sci. Lett., 288: 588-600.

Zhang, W., Wang, Z.C., Moynier, F., Inglis, E.C., Tian, S.Y., Li, M., Liu, Y.S., Hu, Z.C., 2019. Determination of Zr isotopic ratios in zircons using laser-ablation multiple-collector inductively coupled-plasma mass-spectrometry. J. Anal. At. 
Spectrom. 34, 1800-1809. 


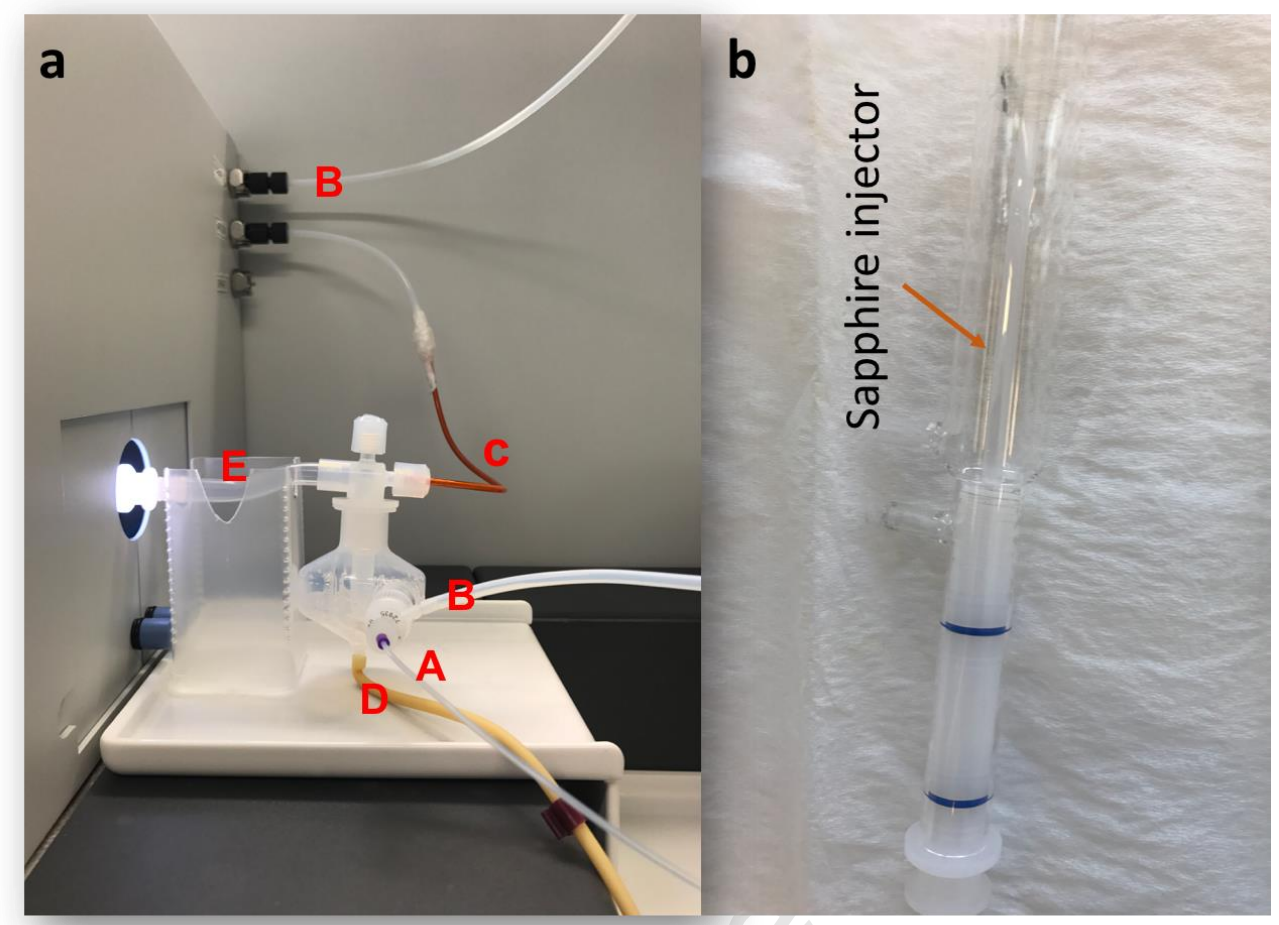

Figure 1 a. Savillex PFA cyclonic spray chamber (CSC) (no surface treatment, part number 820-01). Sample solutions are aspirated by sample gas (B) through the PFA-50 micro-flow nebulizer and assembled sample capillary (A). The make-up gas (C) improves the delivery of nebulizing sample solutions into the torch through the elbow connection (E). The waste droplets go down to the drain (D) at the bottom of the spray chamber. b. Thermo Injector Assembly with Sapphire Injector (1.8 mm ID, precleaned, 851-011-100708) in the torch. 


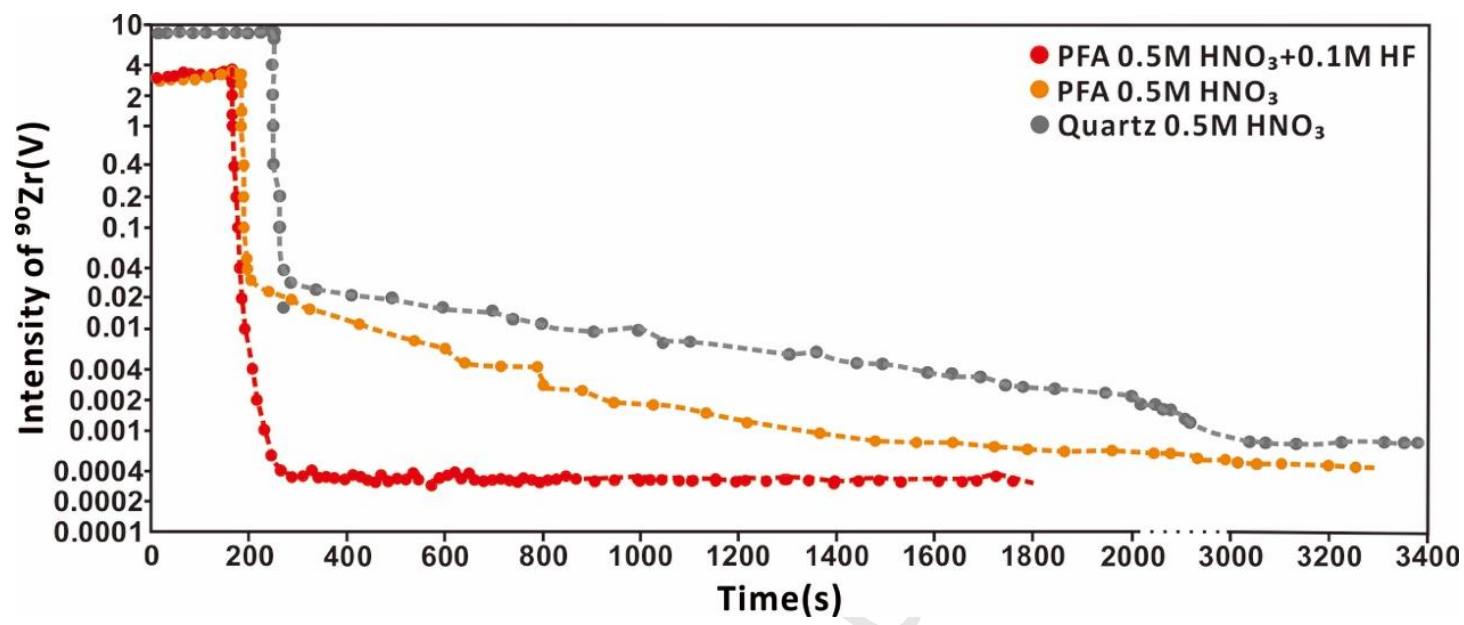

Figure $2{ }^{90} \mathrm{Zr}$ intensity as a function of time during washout of the 200ppb IPGP-Zr solution when using different acids and spray chambers. The difference of the intensity at the same concentration is due to PFA CSC has inferior sensitivity than quartz SIS. 


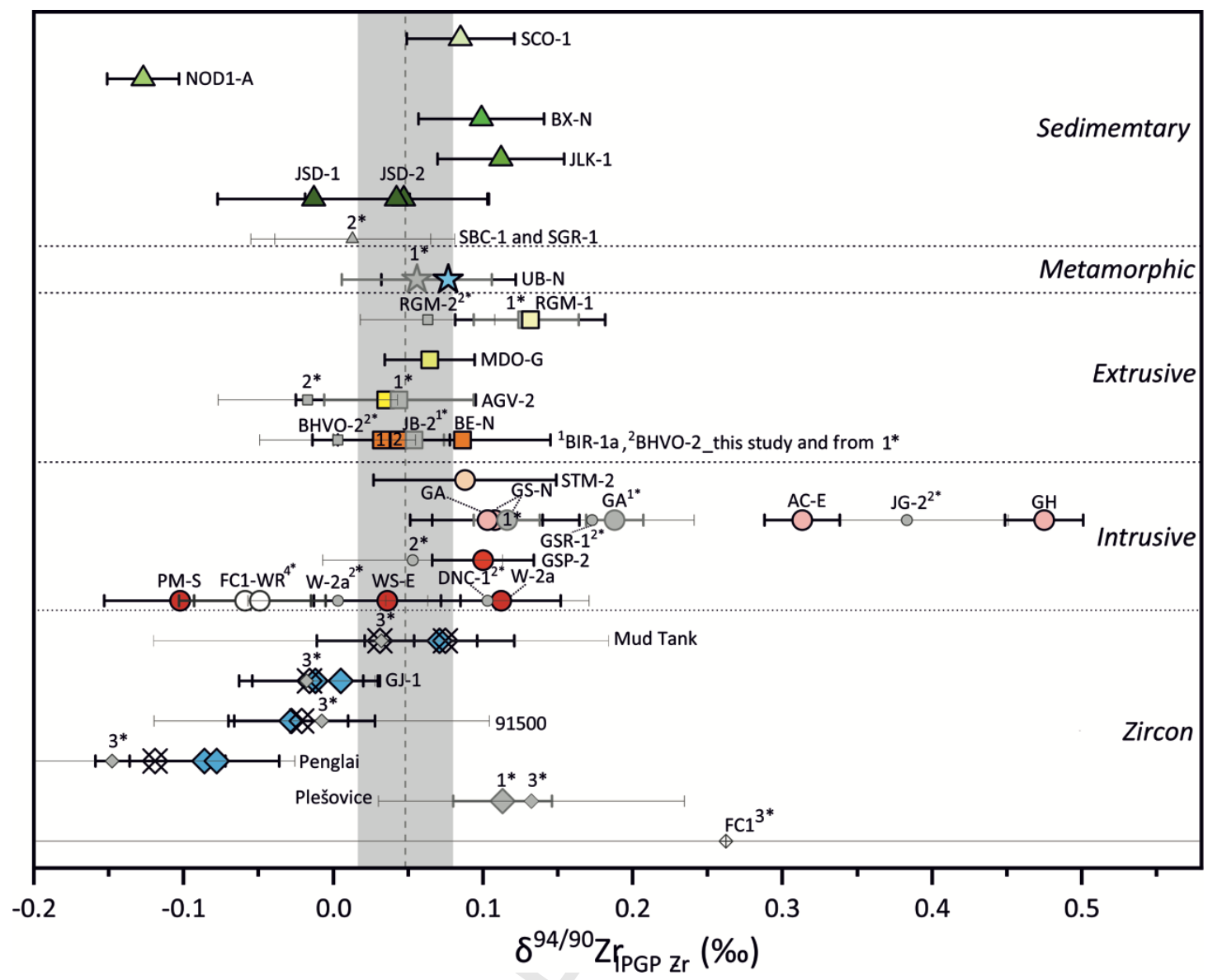

Figure 3 Zirconium isotopic compositions of whole rock and zircon reference materials. Error bars indicate 2SD uncertainties. Colorful symbols with black edge represent the data from this study, plus zircon symbols (diamonds) with cross representing unpurified zircons for distinction from their purified counterparts (diamonds with black edge). Literature data marked with * are from: 1. Inglis et al. (2018); 2. Feng et al. (2020); 3. Zhang et al. (2019); 4. Ibañez-Mejia and Tissot (2019). The gray band denotes $\delta^{94 / 90} \mathrm{Zr}_{\text {IPGP-Zr }}$ value of the upper mantle estimated by Inglis et al. (2019). 


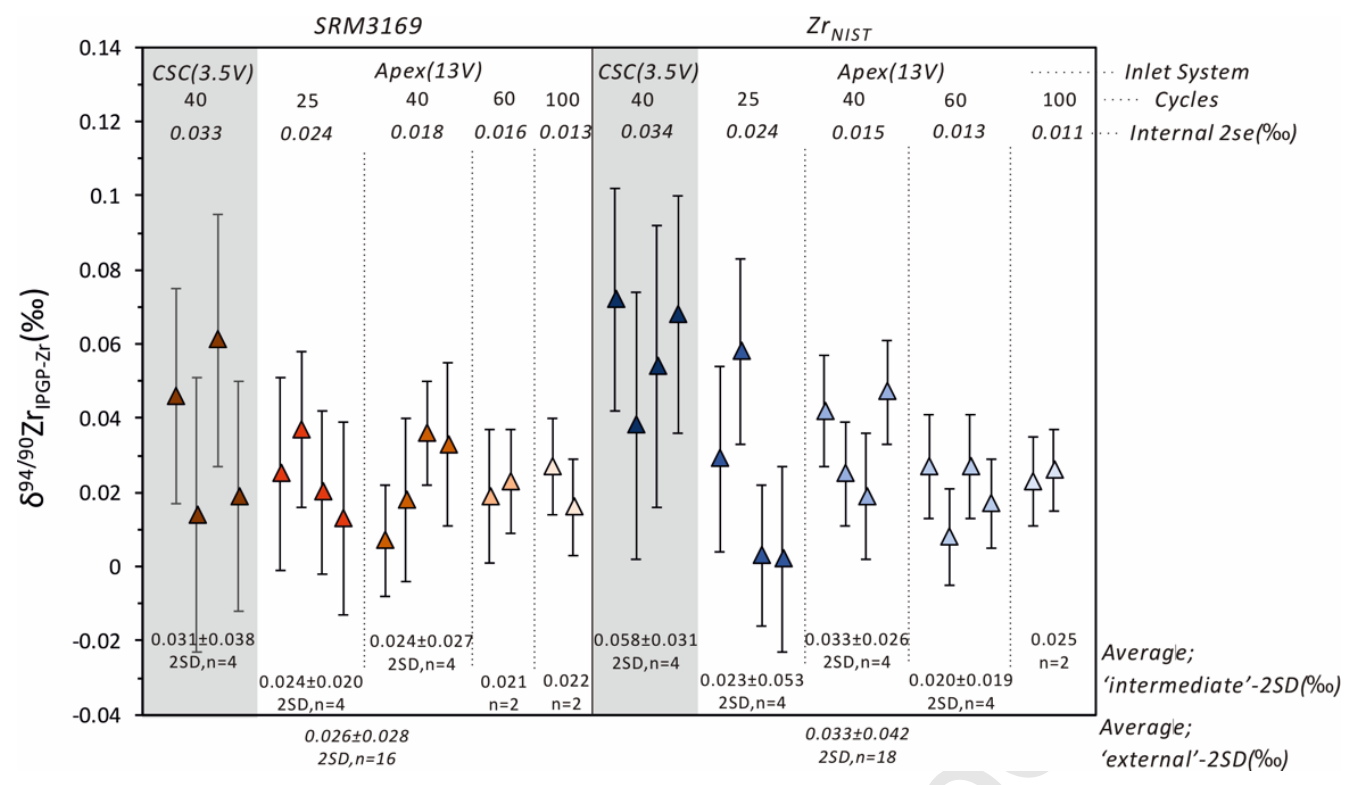

Figure $4 \mathrm{Zr}$ isotope compositions of SRM3169 and NIST. CSC and Apex denote the two different inlet systems with brackets behind them including the signal on ${ }^{90} \mathrm{Zr}^{+}$. Error bars indicate 2se uncertainties within each block. Data can be found in Table S3. 


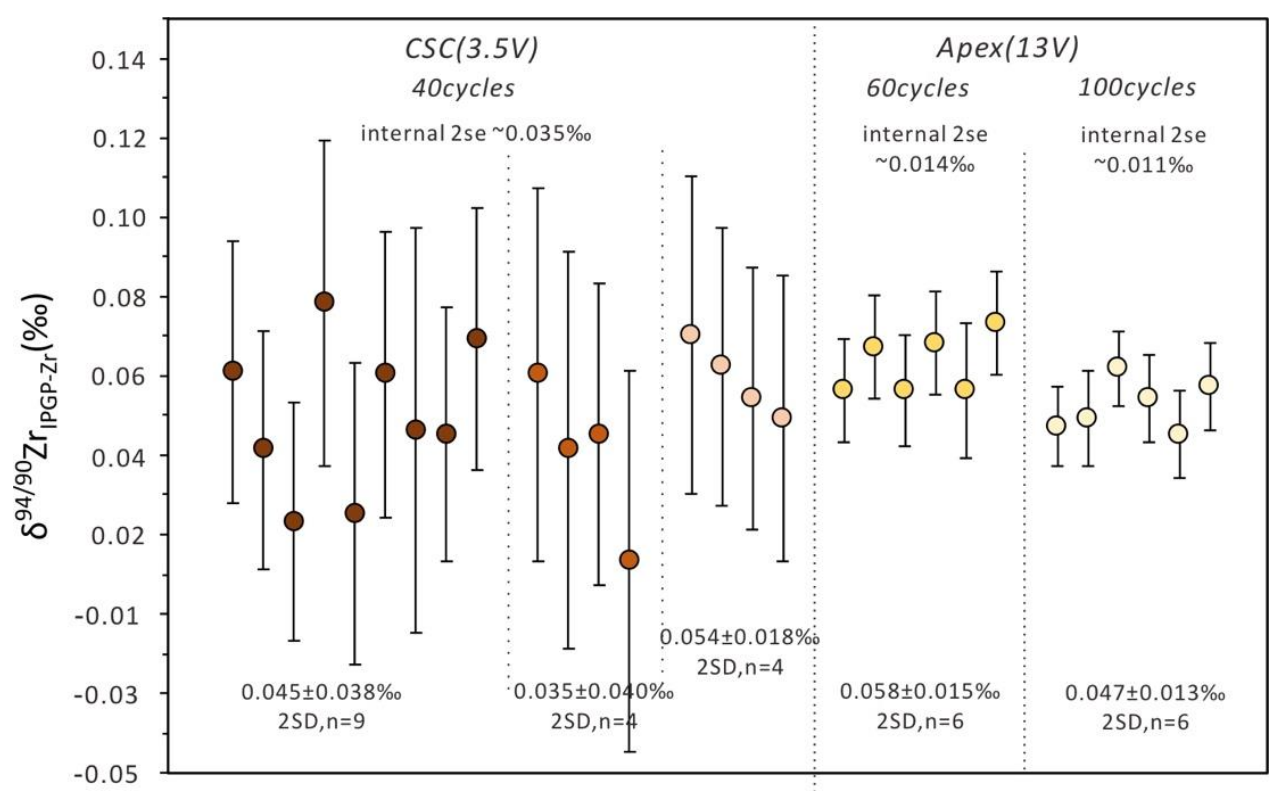

Figure $5 \mathrm{Zr}$ isotope compositions of BHVO-2 analyzed at different conditions. Note that $\delta^{94 / 90} \mathrm{Zr}_{\text {IPGP }}$ values of BHVO-2 measured using CSC showed here are selected randomly from all the measurements because we just want to show the usual internal precision under this condition. Error bars indicate 2 se uncertainties of every analysis. The data below the circles indicate the average values and their 2SD uncertainties of the measurements, $\mathrm{n}$ representing the number of replicates for one aliquot. Data can be found in Table S4 


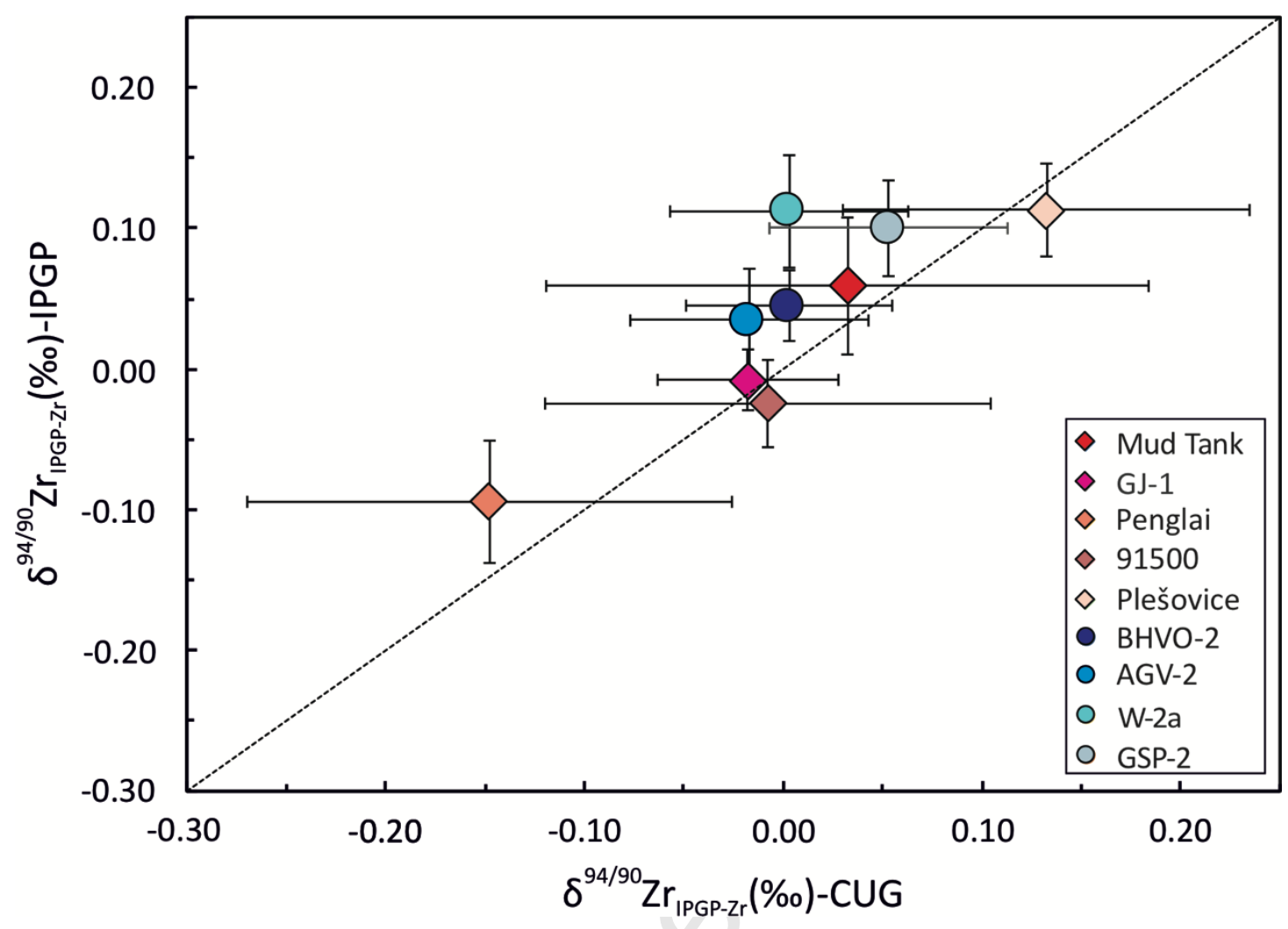

Figure 6 Interlaboratory comparison of $\mathrm{Zr}$ isotope compositions of zircons and RMs.

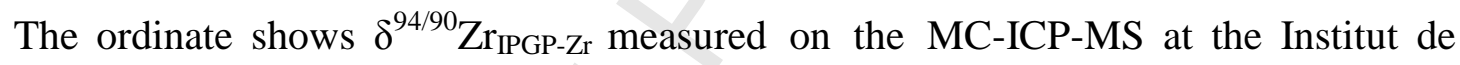
Physique du Globe de Paris (IPGP), among which the $\delta^{94 / 90} \mathrm{Zr}_{\text {IPGP-Zr value of zircon }}$ Plesovice is from Inglis et al. (2018) and others are reported in this study. The horizontal ordinate represents the data of zircon and RMs from Zhang et al. (2019) indicated by red-colored diamonds and Feng et al. (2019) denoted by blue-colored circles which were measured on LA-MC-P-MS and TIMS respectively (CUG denotes China University of Geosciences). The error bars indicate 2SD uncertainties. 
Table 1 Zirconium isotope compositions of zircons

\begin{tabular}{|c|c|c|c|c|c|c|c|c|}
\hline & \multicolumn{3}{|c|}{ purified } & \multicolumn{3}{|c|}{ unpurified } & \multicolumn{2}{|c|}{ LA-MC-ICP-MS $^{\mathrm{a}}$} \\
\hline & $\begin{array}{c}\delta^{94 / 90} \mathrm{Zr}_{\text {IPGP-Zr }} \\
(\% \text { ) }\end{array}$ & $2 \mathrm{SD}$ & $\begin{array}{l}\mathrm{n} \\
\mathrm{b}\end{array}$ & $\begin{array}{c}\delta^{94 / 90} \mathrm{Zr}_{\text {IPGP-Zr }} \\
(\%)\end{array}$ & 2SD & $\begin{array}{l}\mathrm{n} \\
\mathrm{b}\end{array}$ & $\begin{array}{c}\delta^{94 / 90} \mathrm{Zr}_{\text {IPGP-Zr }} \\
(\%)\end{array}$ & $2 \mathrm{SD}$ \\
\hline Mud Tank & & & & 0.075 & 0.021 & 4 & 0023 & (15? \\
\hline Mud Tank-R & 0.071 & 0.050 & 4 & 0.031 & 0.042 & 4 & 0.032 & 0.152 \\
\hline GJ-1 & 0.005 & 0.015 & 4 & & & & م & م \\
\hline GJ-1-R & -0.012 & 0.042 & 4 & -0.016 & 0.047 & 4 & -0.018 & 0.045 \\
\hline Penglai & -0.086 & 0.050 & 4 & -0.119 & 0.04 & 4 & 0148 & 0112 \\
\hline Penglai-R & -0.078 & 0.006 & 4 & & $c$ & & -0.140 & 0.122 \\
\hline 91500 & -0.028 & 0.038 & 4 & -0.021 & 0.049 & 4 & -0.008 & 0.112 \\
\hline Plešovice & & & & 0.113 & 0.033 & 4 & 0.132 & 0.102 \\
\hline FC-1 & & & & & & & 0.262 & 1.900 \\
\hline
\end{tabular}

${ }^{\mathrm{a}}$ The LA-MC-ICP-MS data of zircons are calibrated based on the data from Zhang et al. (2019).

${ }^{\mathrm{b}} \mathrm{n}=$ number of measurements. 
Table 2 Zirconium isotope compositions of standard solutions

\begin{tabular}{llll}
\hline Sample name & $\delta^{94 / 90} \mathrm{Zr}_{\text {IPGP-Zr }}(\%)$ & $2 S D$ & $\mathrm{n}$ \\
SRM3169 & 0.026 & 0.028 & 16 \\
NIST & 0.033 & 0.042 & 18 \\
\hline
\end{tabular}

$\mathrm{n}=$ number of measurements. 
Table 3 Zirconium isotopic compositions of bulk rock reference materials

\begin{tabular}{|c|c|c|c|c|}
\hline Sample name & Description & $\delta^{94 / 90} \operatorname{Zr}(\%$ o) & $2 \mathrm{SD}$ & $\mathrm{n}^{\mathrm{c}}$ \\
\hline BHVO-2 & basalt & 0.054 & 0.018 & 4 \\
\hline Replicate & & 0.061 & 0.041 & 4 \\
\hline Replicate & & 0.035 & 0.040 & 4 \\
\hline Replicate & & 0.045 & 0.038 & 9 \\
\hline Replicate & & 0.036 & 0.031 & 6 \\
\hline Replicate & & 0.025 & 0.067 & 6 \\
\hline Replicate & & 0.058 & 0.015 & 6 \\
\hline Replicate & & 0.047 & 0.013 & 6 \\
\hline Average & & 0.045 & 0.025 & 45 \\
\hline Literature $^{\mathrm{a}}$ & & 0.044 & 0.044 & 8 \\
\hline Literature $^{\mathrm{b}}$ & & 0.003 & $0.052^{\mathrm{d}}$ & 8 \\
\hline \multirow[t]{2}{*}{ BIR-1a } & basalt & 0.044 & 0.045 & 4 \\
\hline & & 0.020 & 0.037 & 4 \\
\hline Literature $^{\mathrm{a}}$ & & 0.041 & 0.054 & 4 \\
\hline BE-N & basalt & 0.086 & 0.059 & 4 \\
\hline \multirow[t]{2}{*}{ AGV-2 } & & 0.051 & 0.051 & 4 \\
\hline & & 0.018 & 0.053 & 4 \\
\hline Average & & 0.035 & 0.037 & 8 \\
\hline Literature $^{\mathrm{a}}$ & & 0.044 & 0.05 & 4 \\
\hline Literature $^{\mathrm{b}}$ & & -0.017 & $0.060^{\mathrm{d}}$ & 6 \\
\hline PM-S & microgabrro & -0.103 & 0.050 & 5 \\
\hline WS-E & dolerite & 0.036 & 0.049 & 4 \\
\hline $\mathrm{W}-2 \mathrm{a}$ & diabase & 0.112 & 0.040 & 4 \\
\hline Literature $^{\mathrm{b}}$ & & 0.003 & $0.060^{\mathrm{d}}$ & 11 \\
\hline MDO-G & trachyte & 0.065 & 0.030 & 4 \\
\hline GSP-2 & granodiorite & 0.100 & 0.034 & 4 \\
\hline Literature $^{\mathrm{b}}$ & & 0.053 & $0.060^{\mathrm{d}}$ & 7 \\
\hline STM-2 & syenite & 0.088 & 0.061 & 4 \\
\hline $\mathrm{GH}$ & granite & 0.475 & 0.026 & 4 \\
\hline AC-E & granite & 0.313 & 0.025 & 4 \\
\hline GS-N & granite & 0.108 & 0.056 & 4 \\
\hline
\end{tabular}




\begin{tabular}{ccccc} 
Literature $^{\mathrm{a}}$ & & 0.116 & 0.022 & 4 \\
GA-1 & granite & 0.087 & 0.035 & 6 \\
Replicate & & 0.122 & 0.066 & 4 \\
Replicate & & 0.098 & 0.060 & 4 \\
Average & & 0.100 & 0.056 & 14 \\
GA-2 & granite & 0.123 & 0.044 & 6 \\
Replicate & & 0.084 & 0.012 & 10 \\
Average & & 0.099 & 0.047 & 16 \\
Literature & & 0.188 & 0.019 & 4 \\
RGM-1 & rhyolite & 0.132 & 0.050 & 2 \\
Literature & & 0.129 & 0.035 & 4 \\
\hline UB-N & serpentinite & 0.056 & 0.05 & 2 \\
Literature $^{\mathrm{a}}$ & & 0.077 & 0.045 & 4 \\
\hline JSD-1 & stream sediments & -0.013 & 0.064 & 4 \\
JSD-2 & stream sediments & 0.047 & 0.057 & 4 \\
Replicate & & 0.042 & 0.061 & 4 \\
JLK-1 & lake sediments & 0.112 & 0.042 & 4 \\
Nod1-A & manganese nodule & -0.127 & 0.024 & 4 \\
SCO-1 & powder & 0.085 & 0.036 & 4 \\
BX-N & shale powder & 0.099 & 0.042 & 4 \\
\hline The & Bauxite & & \\
\hline
\end{tabular}

${ }^{\mathrm{a}}$ The literature data is from Inglis et al. (2018).

${ }^{\mathrm{b}}$ The literature data is calibrated based on the IPGP-Zr value $\delta^{94 / 90} \mathrm{Zr}_{\text {SRM3169 }}=-0.04 \pm$ 0.06\% (2SD, $\mathrm{n}=16$ ) from Feng et al. (2020) and the SRM3169 value $\delta^{94 / 90} \mathrm{Zr}_{\text {IPGP=Zr }}=$ $0.026 \pm 0.028 \%$ o $(2 \mathrm{SD}, \mathrm{n}=16)$. Their average value $=0.033 \pm 0.033 \%$ where the error obtained via error propagation.

${ }^{\mathrm{c}} \mathrm{n}=$ number of measurements.

${ }^{\mathrm{d}}$ The 2SD uncertainties are calibrated via error propagation from the error $0.033 \%$ mentioned in b and those reported in Feng et al. (2020). 


\section{Declaration of interests}

$\bigotimes$ The authors declare that they have no known competing financial interests or personal relationships that could have appeared to influence the work reported in this paper.

$\square$ The authors declare the following financial interests/personal relationships which may be considered as potential competing interests: 
Graphical abstract

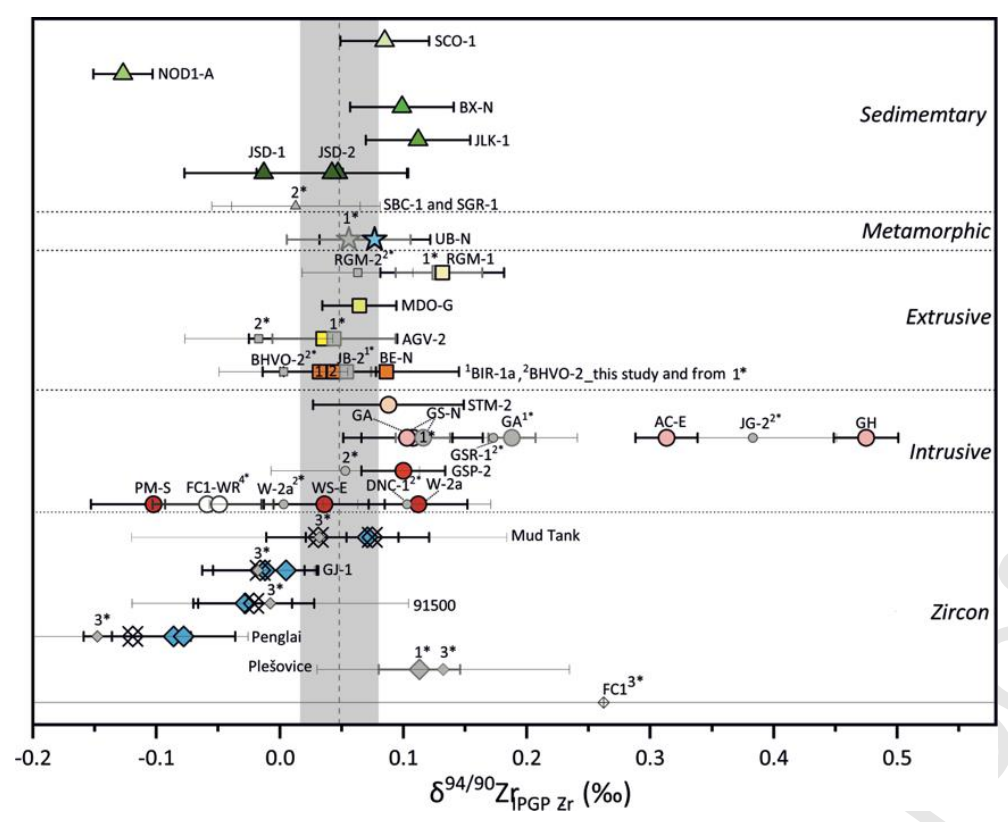

